\title{
INDICE DELL'ANNATA 1997
}

\section{SAGGI}

Perché è difficile costruire le istituzioni

di Massimo Morisi

Quale «democrazia costituzionale»?

La Corte federale nella politica tedesca e il problema della costituzione europea di Gian Enrico Rusconi

Democrazia con aggettivi. L'innovazione concettuale nella ricerca comparata

di David Collier e Steven Levitsky

Pluralismo, multiculturalismo e estranei

di Giovanni Sartori

Cittadinanza differenziata e integrazione multiculturale di Matteo Gianni

\section{RICERCHE}

Il ripensamento del welfare state in Germania e negli Stati Uniti

di Jens Alber

L'evoluzione degli assetti concertativi in Italia e in Germania di Elisabetta Gualmini 
Le politiche della scuola in Europa. Un'analisi comparata

di Sofia Ventura

Crisi economica, istituzioni e rendimento in 17 democrazie di Adriano Pappalardo

L'attività legislativa del Parlamento italiano: consociativismo? Polarizzazione?

di Francesco Zucchini

\section{NOTE}

L'attività legislativa dei governi al tramonto della Prima Repubblica

di Chiara De Micheli

Quale secessione in Italia?

di M. Chiara Barlucchi

\section{RASSEGNE}

Ordine e mutamento nelle relazioni internazionali di Alessandro Colombo

\section{RECENSIONI}

L.J. Alston, T. Eggertsson e D.C. North (a cura di), Empirical Studies in Institutional Change [Luca Lanzalaco]

R. Balme, Ph. Garraud, V. Hoffmann-Martinot e E. Ritaine, Le territoire pour politiques: variations européennes [Margarita Gomez-Reino]

F. Battistelli, Soldati. Sociologia dei militari italiani nell'era del peace-keeping [Luciano Bozzo]

L. Bobbio, La democrazia non abita a Gordio. Studi sui processi decisionali politico-amministrativi [Carlo Baccetti]

O. Borre e E. Scarbrough (a cura di), The Scope of Government [Paolo Segatti] 
M. Braga da Cruz, Instituções políticas e processos sociais [Anna Bosco]

G. Calvi e A. Vannucci, L'elettore sconosciuto. Analisi socioculturale e segmentazione degli orientamenti politici nel 1994 [Alessandro Chiaramonte]

F. Cerutti (a cura di), Identità e politica [Rossana Trifiletti]

A. Costabile, Modernizzazione famiglia e politica. Le forme del potere in una città del Sud [Ettore Recchi]

G. Cox, Making Votes Count. Strategic Coordination in the World's Electoral Systems [Giovanni Capoccia]

L. D'Antone (a cura di), Radici storiche ed esperienza nell'intervento straordinario nel Mezzogiorno [Francesco Ramella]

D. della Porta, Social Movements, Political Violence, and the State. A Comparative Analysis of Italy and Germany [Marco Giugni]

B. Dente, In un diverso Stato. Come rifare la pubblica amministrazione italiana [Gilberto Capano]

J. van Deth e E. Scarbrough (a cura di), The Impact of Values [Paolo Segatti]

J. Elster (a cura di), The Roundtable Talks and the Breakdown of Communism [Giuseppe Ieraci]

F. Fossati, Mercato e Democrazia in America Latina [Liborio Mattina]

R.E. Goodin (a cura di), The Theory of Institutional Design [Luca Lanzalaco]

G. Graziano, Lobbying, Pluralismo, Democrazia [Liborio Mattina]

S. Gundle e S. Parker (a cura di), The New Italian Republic. From the Fall of the Berlin Wall to Berlusconi [Luca Verzichelli]

R.J. Herrnstein e Ch. Murray, The Bell Curve: Intelligen- 
ce and Class Structure in American Life [Giancarlo Gasperoni]

M. Kaase e K. Newton (a cura di), Beliefs in Government [Paolo Segatti]

R. Keohane e H.V. Milner (a cura di), Internationalization and Domestic Policy [Fabio Fossati]

H.-D. Klingemann e D. Fuchs (a cura di), Citizens and the State [Paolo Segatti]

J.E. Lane, Constitutions and Political Theory [Giuseppe Ieraci]

J.E. Lane e S.O. Ersson, European Politics. An Introduction [Marco Giuliani]

L. Lanzalaco, Istituzioni, organizzazione, potere. Introduzione all'analisi istituzionale della politica [Sergio Fabbrini]

M. Laver e K. Shepsle, Making and Breaking Governments. Cabinets and Legislatures in Parliamentary Democracies [Daniela Giannetti]

L. Leduc, R.G. Niemi e P. Norris (a cura di), Comparing Democracies. Elections and Voting in Global Perspective [Alessandro Chiaramonte]

$P$. Le Galès e $M$. Thatcher (a cura di), Les réseux de politique publique. Débat autour des policy networks [Marco Giuliani]

A. Lijphart e C.H. Waisman (a cura di), Institutional Design in New Democracies. Eastern Europe and Latin America [Luca Lanzalaco]

J.J. Linz e A. Stepan, Problems of Democratic Transition and Consolidation. Southern Europe, South America, and Post-Communist Europe [Anna Bosco]

Y. Mény, P. Muller e J.L. Quermonne (a cura di), Politiques publiques en Europe [Paolo Modugno]

W.E. Miller e J.M. Shanks, The New American Voter [Alessandro Chiaramonte]

O. Niedermayer e R. Sinnott (a cura di), Public Opinion and International Governance [Paolo Segatti]

P. Norris e J. Lovendusky, Political Recruitment: Gen- 
der, Race and Class in the British Parliament [Luca Verzichelli]

A.M.L. Parisi e H.M.A. Schadee (a cura di), Sulla soglia del cambiamento. Elettori e partiti alla fine della Prima Repubblica [Francesco Zucchini]

W. Parsons, Public Policy. An Introduction to the Theory and Practice of Policy Analysis [Marco Giuliani]

V. Pérez-Diaz, España puesta a prueba. 1976-1996 [D. della Porta]

T. Risse-Kappen (a cura di), Bringing Transnational Relations Back in. Non State Actors, Domestic Structures and International Institutions [Fabio Fossati]

D. Rometsch e W. Wessels (a cura di), The European Union and Member States. Towards Institutional Fusion? [Claudio M. Radaelli]

J.G. Ruggie, Winning the Peace. America and World Order in the New Era [Fabio Fossati]

R.A. Seltzer, Mistakes that Social Scientists make. Error and Redemption in the Research Process [M. Chiara Barlucchi]

K.A. Shepsle e C.R. Weingast (a cura di), Positive Theories of Congressional Institutions [Francesco Zucchini]

G. Sola, Storia della scienza politica. Teorie, ricerche e paradigmi contemporanei [G. Pasquino]

S. Strange, The Retreat of the State. The Diffusion of Power in the World Economy [Fabio Fossati]

P. Turi, L'ultimo segretario. Vita e carriera di Alessandro Natta [Anna Bosco]

S. Vaughn, J. Shay Schumm e J. Sinagub, Focus Groups Interviews in Education and Psychology [M. Chiara Barlucchi]

S. Verba, K. Lehman Schlozman e H.E. Brady, Voice and Equality: Civic Voluntarism in American Politics [Paolo Feltrin]

D. Verdier, Democracy and International Trade. Britain, France and the United States, 1860-1990 [Fabio Fossati] 